\title{
O negócio jurídico processual e a promessa de não processar
}

\author{
The procedural legal business and the promise not to sue \\ El negocio jurídico procesal y la promesa de no demandar
}

Recebido: 03/05/2021 | Revisado: 10/05/2021 | Aceito: 14/05/2021 | Publicado: 31/05/2021

\author{
Kelly Cardoso \\ ORCID: https://orcid.org/0000-0002-0216-9809 \\ Universidade Paranaense, Brasil \\ E-mail: servjuskelly@gmail.com \\ Edivan José Cunico \\ ORCID: https://orcid.org/0000-0002-7883-0253 \\ Universidade Paranaense, Brasil \\ E-mail: edivanjcunico@hotmail.com \\ José Laurindo de Souza Netto \\ ORCID: https://orcid.org/0000-0002-6950-6128 \\ Universidade Paranaense, Brasil \\ E-mail: professorlaurindo@unipar.br
}

\begin{abstract}
Resumo
O pactum de non petendo a despeito de não ser novo instituto ganha nova abordagem diante da atual tratativa processual. Decorrente da Lei de Organizações Criminosas e do acordo de não persecução penal, o tema tornou-se relevante também ao processo civil. Objetiva-se expor brevemente sobre os conceitos de fato jurídico e negócio jurídico, juntamente com princípios pontuais que regem o pactum de non petendo. A problematização se encontra na possibilidade ou não das partes pactuarem promessa de não processar como meio de auxiliar a perspectiva cooperativa consensual de resolução de conflitos. Para tanto, utiliza-se da análise bibliográfica como metodologia, em especial do autor Alberto Trigo, além da legislação pertinente.
\end{abstract}

Palavras chave: Negócio jurídico; Pactum de non petendo; Meio consensual de resolução de conflito.

\begin{abstract}
The pactum de non petendo in spite of not being a new institute gains a new approach in face of the current procedural approach. As a result of the Criminal Organizations Law and the non-criminal prosecution agreement, the issue has also become relevant to civil proceedings. The objective is to briefly expose the concepts of legal fact and legal transaction, together with specific principles that govern the pactum de non petendo. The problematization is found in the possibility or not of the parties to agree on a promise not to sue as a means of assisting the consensual cooperative perspective of conflict resolution. For this purpose, bibliographic analysis is used as a methodology, especially by the author Alberto Trigo, in addition to the relevant legislation.
\end{abstract}

Keywords: Legal transaction; Pactum of non petendo; Consensual means of conflict resolution; Self-composition.

\section{Resumen}

El pactum de non petendo a pesar de no ser un instituto nuevo adquiere un nuevo enfoque frente al actual enfoque procesal. Como resultado de la Ley de organizaciones criminales y el acuerdo de enjuiciamiento no penal, el tema también se ha vuelto relevante para los procedimientos civiles. El objetivo es exponer brevemente los conceptos de hecho jurídico y negocio jurídico, junto con los principios específicos que rigen el pactum de non petendo. La problematización se encuentra en la posibilidad o no de que las partes se pongan de acuerdo sobre una promesa de no procesar como medio para ayudar a la perspectiva cooperativa consensuada de resolución de conflictos. Para ello, se utiliza como metodología el análisis bibliográfico, especialmente por parte del autor Alberto Trigo, además de la legislación pertinente.

Palabras clave: Negocios jurídicos; Pactum de non petendo; Medios consensuales de resolución de conflictos; Autocomposición.

\section{Introdução}

Com a evolução do Direito, percebe-se que temas antigos se tornam atuais, necessitando serem estudados para a devida aplicação na prática jurídica diária. Dentro dessa perspectiva, é necessário entender o básico do universo jurídico, sendo os conceitos e ideias de fato jurídico, norma, negócio jurídico, processo, dentre outros, para a adequada construção do conhecimento referente ao tema proposto, qual seja, a promessa de não processar. 
O presente artigo, ao longo de seu texto, busca entender como aplicar na prática o pacto de não postular, quais os problemas e conflitos reais, não apenas teóricos do assunto, e por que uma matéria que está presente desde o direito romano, vem sendo estudada recentemente.

São escassos os estudos realizados no Brasil cujo enfoque seja o pactum de non petendo, até porque o tema estava adormecido, só acordando atualmente, como já mencionado. No âmbito internacional, existem diversos estudos, mas não próprio e especificamente para o tema, sendo sempre inseridos em algum contexto.

Dessa forma, o propósito do presente estudo foi analisar a visão do advogado Alberto Trigo, o primeiro autor brasileiro a escrever sobre o tema, interpretando a questão trazida em seu livro, e frisando a importância das resoluções consensuais de conflitos através dos institutos da conciliação, mediação e arbitragem.

\section{Metodologia}

A pesquisa utilizou-se do método dedutivo, que segundo Eva Maria Lakatos e Marina de Andrade Marconi (2003, p. 92), seus argumentos estão corretos ou incorretos ou as premissas são capazes de sustentar a conclusão em sua totalidade.

A dedução parte da análise da doutrina, especialmente do trabalho de Alberto Trigo, bem como, legislação.

Para a composição argumentativa, parte-se da abordagem do direito material com a apresentação dos conceitos de fato jurídico e negócio jurídico, com intuito de caracterizar o negócio jurídico processual e sua importância na atual tratativa aplicado ao processo como meio de autocomposição de conflitos.

\section{Resultados e Discussão}

\subsection{Fato jurídico}

O estudo dos fatos jurídicos, no direito material, ainda com o Código Civil de 1916, tem sua importância para a averiguação de quais fatos terão relevância jurídica gerando respectivos efeitos. Segundo afirmam Farias e Rosenvald:

A vida é uma sucessão de acontecimentos, fatos, originados por vezes das forças da natureza e outras oportunidades da conduta humana. $\mathrm{O}$ valor desses acontecimentos diuturnos, todavia, não é igual. Ao revés. Surge a norma jurídica exatamente para sopesar o valor dos fatos. E, outras palavras, a norma irá qualificar, adjetivar, os fatos cotidianos, juridicizando-os (2016, p. 568).

De acordo com Miranda (1954, p. 77) fato jurídico se define como: o fato ou complexo de fatos sobre o qual incidiu a regra jurídica; portanto, o fato de que dinama, agora, ou mais tarde, talvez condicionalmente, ou talvez não diname, eficácia jurídica (efeito jurídico).

Por exemplo, conforme Pereira (1997, p. 245), a chuva é um fato que ocorre e que continua acorrer, dentro da normal indiferença jurídica, o que não quer dizer que algumas vezes este mesmo fato não repercuta no campo do direito para estabelecer, alterar numa situação jurídica.

Os raios em um tempo chuvoso são considerados um fato, contudo, só se tornarão um fato efetivamente jurídico quando destruírem os eletredomésticos que guarnecem uma residência, sendo acobertados pelo seguro contratado pelo proprietário da casa com uma seguradora.

Além dos eventos naturais diz Pereira (1997, p.245), outros fatos se dão com relação às ações do homem. Segundo ele ainda, o indivíduo veste-se, alimenta-se, sai de casa e a vida jurídica se montra alheia a essas situações, a não ser quando a locomoção, a alimentação, ou vestuário provoquem a atenção do ordenamento legal.

Os fatos jurídicos em sentido amplo podem ser divididos em fatos jurídicos em sentido estrito, atos-fatos jurídicos e atos jurídicos em sentido amplo. 
"O fato jurídico em sentido estrito, também chamado de fatos naturais, são os que acontecem independente da vontade humana, e são divididos em ordinários, como por exemplo, o nascimento, a morte, o decurso do tempo; e extraordinários, como terremoto ou uma tempestade" (Leite, 2020).

Os atos-fatos jurídicos, por sua vez, deixam em relevo a consequência do ato sem levar em consideração a vontade de praticar, como exemplo, a compra de um doce por uma criança ou a descoberta de um tesouro, nesses dois casos o elemento da vontade fica em segundo plano, importando a consequência, ou seja, o fato de que adquiriram a propriedade do doce e do tesouro.

Já os atos jurídicos em sentido amplo, são basicamente, segundo Gonçalves (2013, p.318), as ações humanas que criam, modificam, transferem, ou extinguir direitos. Nesse caso, ao contrário dos atos-fatos jurídicos, existe uma manifestação consciente da vontade para alcançar um resultado que é juridicamente previsto.

Os atos jurídicos em sentido amplo podem ser divididos em ato jurídico em sentido estrito (ato não negocial), e em negócio jurídico (ato negocial).

Um ato jurídico em sentido estrito tem o efeito da manifestação de vontade, já está previamente fixado pela lei, como acontece no caso de reconhecimento de um filho, em que já são pré-determinados alguns efeitos, como por exemplo, o dever de prestar alimentos.

Já o negócio jurídico, que são mais relevantes para o direito, será explanado a seguir, em tópico próprio, para melhor compreensão.

\subsubsection{Negócio jurídico}

Os fatos jurídicos em sentido amplo são subdivididos em fatos jurídicos em sentido estrito, atos-fatos jurídicos, a atos jurídicos em sentido amplo. Dentro dos atos jurídicos em sentido amplo, subdivide-se em atos jurídicos em sentido estrito e negócios jurídicos (Leite, 2020).

Farias e Rosenvald conceituam negócio jurídico como:

[..] acordo de vontades, que surge da participação humana e projeta efeitos desejados e criados por ela, tendo por fim a aquisição, modificação, transferência ou extinção de direitos. Há, nesse passo, uma composição de interesses, tendo a declaração de vontades um fim especial. A vontade é apenas para aderir aos efeitos previstos na ordem jurídica, respeitando os pressupostos de validade e eficácia impostos pela norma (2016, p. 584).

A diferença com relação aos atos jurídicos, segundo Lotufo (2004. p.261), é no sentido em que enquanto nos atos jurídicos se tem uma ação e uma vontade simples, nos negócios jurídicos, se tem uma ação e vontade qualificada, que é produzir um efeito jurídico determinado. A vontade caracterizada por sua finalidade específica, que é a constituição, modificação e extinção de direitos.

Importante notar que o negócio jurídico não está restrito ao direito patrimonial, mas pode se manifestar também em outras áreas do direito, como por exemplo, no direito de família, no direito de personalidade.

A despeito de autonomia privada constar como um dos elementos do negócio jurídico, por certo, trata-se de um acordo de vontades, contudo, o negócio jurídico, principalmente no âmbito contratual sofreu alterações em relação a externalização da vontade. Como afirma Fiuza:

Dizer simplesmente que os contratos são fruto de um acordo de vontades, é dizer muito pouco, além de se correr o risco de se descambar para um voluntarismo oitocentista cego, que vê o contrato como um mero fenômeno da vontade. Na verdade, que acordo de vontades há, quando uma pessoa toma um ônibus urbano, ou requisita a ligação de luz ou telefone e sua casa? Seguramente, não há acordo de vontades autônomas, como se queria no século XIX. 
Há, porém, uma convergência de atitudes, de ações movidas por necessidades ou desejos. Há, pois, convenção (2016, p.523-524).

Gagliano e Pamplona Filho (2020, p.346), justificam essas mudanças interpretativas alegando que o direito contemporâneo reconheceu que os agentes emissores da vontade não podiam ser sempre considerados partes iguais em uma dada relação jurídica, sob pena de se coroar em algumas situações de negável injustiça.

Nesse contexto, a igualdade formal passou a dar lugar a igualdade material e a proteção da dignidade da pessoa humana, de modo que se modificou inclusive a interpretação do negócio jurídico, sobretudo com relação à sua principal espécie, que é o contrato.

\subsection{Fato jurídico processual}

Veja-se que é possível aos sujeitos interessados por meio de contrato particular, portanto entre privados, realizem negócios jurídicos, e esses negócios jurídicos, como uma compra e venda, como a locação, ou com outros tantos negócios jurídicos, podem ser realizados e determinar regras e condutas de direito privado.

Todavia, o negócio jurídico também pode ter uma vertente processual, neste caso, fala-se de negócio jurídico processual ou convenções processuais.

Isso se dar, por exemplo, quando as partes por meio de acordo entre elas fazem uma determinação processual ou estipulam regras de procedimento.

Pode acontecer isso no próprio contrato de compra e venda, quando as partes elegem o foro, ou quando as partes por meio de um contrato de prestação de serviço, ou ainda, de entrega de coisa, determina que para eventual processo judicial envolvendo o litígio em questão, deva funcionar o sujeito "A" com perito.

Os negócios jurídicos processuais são classificados como sendo típicos, que são aqueles taxados no Código como tal, ou como atípicos, que são aqueles que não estão taxados pelo Código, mas que podem ser criados pelas partes, e que tem como base o artigo 190 do CPC e as suas determinações.

Existem dois momentos para realizar o negócio jurídico processual. Primeiro momento, se ele é pré-processual, portanto, realizado antes da instrução processual, por exemplo, aquele negócio de fixação da cláusula de eleição de foro.

E em segundo momento, é a realização de negócios jurídicos processuais no curso do processo, já no meio da estrutura do processo. Um exemplo é o saneamento programado, que está previsto no artigo 357, parágrafos, do CPC que vai efetivamente dizer que as partes podem convencionar sobre o saneamento do processo. Assim, as partes definem as questões controvertidas e fixam os pontos a serem debatidos.

Analisando os limites do negócio jurídico processual, tem-se só se pode convencionar sobre questões de procedimento e não sobre questões do processo. A exemplo, não se pode realizar um negócio jurídico processual que diga que eventual futuro processo não fará a coisa julgada. Ou ainda, não se pode fixar em um eventual negócio jurídico processual, que os pressupostos do processo serão diferentes, caso se proponha uma ação no futuro.

Em suma, regras de processo não são convencionadas, não são negociadas. Regras de procedimento sim, como a fixação de ônus da prova.

Frisa-se que esses negócios jurídicos processuais não podem ofender os direitos dos consumidores e muito menos em correr em situação prejudicial. O controle se fará por meio do próprio poder judiciário, ou seja, o juiz será quem fiscalizará os negócios jurídicos processuais. 


\section{Princípios do Negócio Jurídico Relacionados ao Processo Civil e ao Pactum de Non Petendo}

Para Nery Junior (2010, p.34,35) os conceitos de norma, princípio, regra, direito e garantia não são uniformes na doutrina. Ele ainda menciona que o problema é tratar o tema mediante sincretismo, ou seja, misturando teorias, assim, justifica o motivo pelo qual até o momento não adotou nenhuma das correntes existentes. Para o autor, todas as teorias têm seus méritos, suas falhas, suas vantagens e desvantagens, assim como as coerências e incoerências.

O ilustre professor Medina (2013) também expressou preocupação com o uso impreciso do termo "princípio", por exemplo, referindo-se à dignidade da pessoa humana (art. 1. ${ }^{\circ}, \mathrm{III}$, da CF), ao contraditório, à boa-fé objetiva e ao próprio dever de cooperação (será analisada a seguir).

Para Medina, embora muitas vezes sejam designados como princípios, esses fenômenos não pertencem necessariamente à mesma categoria jurídica, e muitas vezes nem deveriam ser chamados de princípios.

O fato é que essa questão, de conceituar princípio, é muito complexa, entretanto, como não é o foco da presente pesquisa, sejamos breves.

Para Barroso (1999, p.147) “são o conjunto de normas que espelham a ideologia da Constituição, seus postulados básicos e seus fins. Dito de forma sumária, os princípios constitucionais são as normas eleitas pelo constituinte como fundamentos ou qualificações essenciais da ordem jurídica que institui”".

Destacar-se-ão aqui dois princípios, o do autorregramento da vontade das partes e o da cooperação. A razão pela qual a análise desses dois princípios é enfatizada, é que eles correspondem à extrema importância que é considerada a base das questões jurídicas processuais. No entanto, o princípio da liberdade (que será analisado mais tarde) e o princípio da operação também podem ser mencionados aqui.

\section{Respeito ao Autorregramento da Vontade das Partes}

Esse princípio é de suma importância, pois distingue os negócios jurídicos dos atos jurídicos em sentido estrito. Para Miranda (1999, p.126), a característica do autorregramento da vontade das partes, é que, independentemente do ramo do direito em que se encontra, ela tem o poder de apoiar o ato jurídico com os elementos centrais da vontade.

Diferentemente do princípio da autonomia da vontade, porque, com isso, se eliminaria qualquer autorregramento da vontade em direito público, o que está errado.

A teoria dos assuntos jurídicos desenvolve-se com base na relação jurídica de direito privado e é orientada pela autonomia do direito privado. Os participantes do negócio jurídico criam, modificam ou eliminam a relação justa.

$\mathrm{O}$ direito fundamental à liberdade, previsto no artigo $5^{\circ}$, caput, da $\mathrm{CF}$, tem conteúdo complexo e, como princípio (princípio da liberdade), também desempenha um papel no processo, resulta um princípio secundário: o princípio do autorregramento da vontade das partes no processo, que por sua vez, apresenta-se como uma dimensão inestimável da dignidade humana, sendo definida como um complexo de poder que pode ser exercido pelas pessoas jurídicas em graus diversos de acordo com o ordenamento jurídico.

Pode-se verificar o exercício do autorregramento da vontade em quatro zona, são elas: (i) liberdade de negociação; (ii) liberdade de criação; (iii) liberdade de estipulação; e (iv) liberdade de vinculação (Nogueira, 2016, p. 137).

O Código de Processo Civil prestigia a autonomia da vontade das partes em diversos dispositivos, como o artigo 190 e como exemplo, a autocomposição, que regula a mediação e a conciliação (artigos 165 a 175), inserindo a tentativa de autocomposição como ato anterior à defesa do réu (artigos 334 a 695) e permitindo, no acordo judicial, a inclusão de matéria estranha ao objeto litigioso do processo (artigo 515, $\S 2^{\circ}$ ). 
O autorregramento da vontade no Código de Processo Civil é permitido, assegurado e respeitado, pois percebe-se que a forma como o diploma é construído visa estimular a resolução de conflitos da forma que mais se adequa a cada situação, ao invés de estabelecer a jurisdição como a melhor opção para eliminar as disputas de interesses.

Embora o princípio do respeito ao autorregramento da vontade não esteja previsto expressamente no CPC atual, o mesmo já era abarcado pelo CPC/1973, assim, deve ser inserido no rol de normas fundamentais do processo civil, pois está contido implicitamente no referido diploma.

\subsection{Cooperação}

$\mathrm{O}$ artigo $6^{\circ}$ do CPC prevê que "Todos os sujeitos do processo devem cooperar entre si para que se obtenha, em tempo razoável, decisão de mérito justa e efetiva", trazendo, o princípio da cooperação como uma das normas fundamentais do processo civil.

Este princípio desempenha duas importantes funções no sistema jurídico brasileiro: (i) estruturar o processo civil sob o modelo cooperativo; e (ii) firmar o funcionamento do sistema processual a partir do princípio da cooperação.

Entre os objetivos principais do princípio da cooperação estão o combate ao desperdício, a tomada de decisões com base no mérito e não em decisões processuais, a busca da verdade e a utilização de métodos administrativos adequados à efetivação de direitos.

Portanto, é certo que o princípio da cooperação parte do próprio sistema democrático, que exige a participação de todos os que podem ser afetados pelo exercício da jurisdição. Nesse processo, as partes e tercei ros devem tomar as decisões em conjunto com o juiz, visando a cooperação.

Existe uma relação inegável entre o princípio da cooperação e o autorregramento da vontade. Na medida em que o modelo cooperativo constrói o sistema a fim de se tornar mais receptivo aos negócios jurídicos processuais, respeitando à atuação das partes no processo, eliminando o dogma da irrelevância da vontade no processo e estimulando os juízes a adotarem uma postura menos autoritária e mais comunicativa.

Por outro lado, o princípio da cooperação funciona como limite objetivo à celebração dos negócios jurídicos processuais, sendo vedada, por exemplo, convenção que afaste os deveres inerentes à colaboração.

O acordo processual indica que o procedimento não é "obra" exclusiva do juiz ou das partes e, como no procedimento arbitral, o modelo processual cooperativo tende a se desenvolver.

Desde que o negócio jurídico processual esteja pautado no princípio da cooperação, pode-se afirmar que, o ambiente cooperativo permite que a vontade convirja a ponto de se tornar o processo e procedimento mais adequado para uma causa específica, que é o escopo dos procedimentos atípicos.

\section{Pactum de Non Petendo}

O pactum de non petendo não é tema novo. Ocorre que existe um artigo português sobre o tema, publicado pela Professora Paula Costa e Silva, alguma coisa na Doutrina Italiana, não suficiente para uma compreensão sobre o tema, e outros poucos conteúdos na Doutrina Francesa, porém antigas, por volta do século XVI e XVII.

Atualmente no Brasil, temos apenas um livro publicado sobre o assunto, o do Alberto Lucas Albuquerque da Costa Trigo (2020), o qual será baseado esse tópico.

O tema em questão estava adormecido, entretanto, nos últimos tempos ganhou relevância no sistema brasileiro quando com a Lei de Organizações Criminosas (Lei no 13.964/2019) veio a previsão do acordo de não persecução penal. 
No artigo 28-A do Código de Processo Penal, traz a ideia e tendência da justiça consensual, regulamentando pelo "Pacote Anticrime", o acordo de não persecução penal (ANPP), que propõem sanar problemas enfrentados relacionados a morosidade de resoluções dos processos judiciais criminais, combater a corrupção e trazer celeridade as demandas judiciais.

Já no Direito Civil, percebeu o surgimento lá no artigo 190 do Código de processo Civil, já mencionado aqui no presente artigo, onde nas convenções processuais é possível as partes a faculdade e direito sobre o próprio procedimento, desde que o direito admita a autocomposição. Assim, pode-se ver que não se trata de direito disponível e sim de direitos que admitam a autocomposição, ou seja, a ideia vai além disso.

Dessa forma, começa a se ter várias possibilidades interessantes, fora daquelas já conhecidas, como as partes convencionarem a competência, ou cláusula compromissória enquanto negócio processual, convenção sobre o ônus da prova, ou até mesmo sobre o saneamento, onde as partes têm a possibilidade de fixar os pontos controvertidos, e ainda, a possiblidade das partes restringirem a existência de prova pericial de forma que cada um apresenta por conta própria o seu laudo, comum na arbitragem.

Importante fazer uma distinção entre acordos dispositivos e acordos obrigacionais. Sendo acordos dispositivos aqueles que versam sobre procedimento específico, como por exemplo, prazo, e acordos obrigacionais são aqueles que versam sobre direitos e deveres, ônus, faculdade das partes.

Por isso, o pactum de non petendo, é uma espécie de acordo obrigacional, em que a parte tem um direito de buscar a pretensão dela em juízo ou junto a um Tribunal Arbitral, e ela vai decidir que por tempo determinado ou indeterminado não irá fazer isso.

Ainda é uma questão bem controversa na doutrina, pois alguns autores fazem confusão entre o pactum de non petendo com o acordo sobre direito material, sendo que parte diz que o pacto é procedimento processual, ainda que incide sobre a pretensão.

O problema disso, é que mesmo incidindo sobre a pretensão, a mesma não está no direito processual, e sim no material. Gera problemas práticos, como confusão na prescrição e na obrigação natural.

Existe assim, não apenas a necessidade de incidir a pretensão como um todo, mas sobre alguns aspectos ou alguns instrumentos novos, como por exemplo, a parte renunciar a direito de crédito de forma que possa buscar sua pretensão no juizado especial cível.

Diante do exposto, Trigo (2020, p. 58) conceitua o pactum de non petendo, como o "negócio processual por meio do qual determinada parte comprometesse, de forma temporária ou definitiva a não exigir direito ou parte dele, podendo também prometer não se valer de um mecanismo processual ou procedimental a que teria direito, para a satisfação da obrigação".

Dessa maneira, a promessa de não processar pode incidir sobre a pretensão do direito processual, e isso é fundamental para desviar de um debate histórico sobre a disponibilidade ou não da ação.

Ação por outro lado, passa por um problema por ser direito inato, onde ninguém pode abrir mão de ação processual, com base no artigo $5^{\circ}$, inciso XXXV da CF, onde desse ponto de vista, a promessa de não processar seria inadmissível.

Contudo, o pacto aqui discutido, não tem a ver com a ação, pois o direito de acesso não é negado, tal qual acontece com a cláusula compromissória, ela depende da alegação das partes em que se beneficiam.

Pode-se ainda, realizar a promessa de não processar sobre parte de um direito e não dele no geral, como no caso de uma celebração de cláusula compromissória, em que parte será regulamentada por uma matéria em específico e a outra parte, um procedimento comum.

Um exemplo bem interessante está no direito de família, nas relações familiares, onde os pais se divorciando, o menor fica tutelado pela mãe, convencionam que em caso de inadimplemento da pensão alimentícia, o pai não sofrerá com a prisão civil. Isso em muitos casos é de relativa significância para a criança. 
Outro ponto de relevância é o momento de celebração do negócio jurídico com a promessa de não processar. Esses acordos podem ser aclamados antes do processo judicial, sendo fundamentais, isso porque esse é um momento específico em que as partes não pensam com animosidade, ou seja, no momento em que as coisas estão mais fáceis de acontecer em termos de contratação.

Último ponto que merece consideração aqui, é o pactum de non petendo com relação a prescrição. Pois ora, se o pacto incide sobre a pretensão de direito material, ele incide sobre a mesma coisa que incide a prescrição, criando uma obrigação natural, temporária ou ilimitada. A obrigação natural ela pode ser conhecida de ofício pelo juiz, e não é o que ocorre com o pacto.

Por isso, se falar que o pactum de non petendo incide sobre o direito processual, consegue criar uma independência do pacto em relações obrigacionais naturais, como por exemplo, obrigação prescrita e dívida de jogo.

Em outras palavras, e mais simples, a promessa de não processar não faz nada com a prescrição, porque no direito brasileiro, especificamente no artigo 192 do CC, há uma previsão expressa falando que as partes não podem dispor sobre o prazo prescricional, que as partes só podem renunciar o prazo prescricional depois de consumado.

Em suma, o pactum de non petendo, não influencia na prescrição, ela continua a correr normalmente, e se em eventual prazo a parte não exigir a dívida, a mesma, se torna prescrita. Visto que a promessa de não postular, no início da celebração do contrato, em momento algum afasta qualquer tipo de exigibilidade do crédito, ela pode afastar alguns tipos de exigibilidade, ou seja, incidindo sobre parte do contrato, e não em regra, nele total.

Veja-se, o pacto não impede que a parte leve o crédito a protesto, cobrança extrajudicial, a fim de garantir o valor, entretanto, a prescrição sim, ela impede a cobrança judicial ou extrajudicial. A inexistência de pretensão do direito material, de responsabilidade, leva a impossibilidade de qualquer tipo de cobrança, caso oposto ao pactum de non petendo.

O momento para se alegar a cláusula de non petendo, quando uma das partes violou o negócio judicial e a outra instaurou ação ou procedimento arbitral, é em preliminar, que seria o tipo mais tradicional, ou em petição específica, mas ainda não confirmada pelo judiciário.

Por fim, será apresentado brevemente na sequência, as espécies de pactum de non petendo.

\subsection{Espécies de promessa de não processar}

Tem-se que o pacto de non petendo possui algumas espécies, dentre elas a (i) cláusula de mediação; (ii) pactum de non exequendo; (iii) e, cláusula solve et repete.

Cláusula de mediação é uma espécie de pactum de non petendo, chamada de cláusula de paz. Aqui, as partes que celebrarem o contrato, comprometem-se a executar o mesmo com lealdade e boa-fé, e caso ocorra algum conflito, elas se comprometem a igualmente buscar a solução negociada.

Dessa maneira, significa dizer que antes de surgir um litígio, as partes se comprometem a buscarem a autocomposição para resolver a questão. E, a cláusula de non petendo estabelece uma causa da proibição temporária, pois antes da instauração de um processo, deverá a parte buscar a conciliação ou a mediação.

Isso afeta os requisitos processuais, quando a parte envolvida quando pleitear o pedido judicial, e essa ação poderá ser extinta, uma vez que a promessa firmada entre as partes cria a possibilidade de extinção da ação.

A cláusula de paz não norma abstrata prevista nas possíveis partes de um vestígio, mas uma convenção processual que pode ser inserida em um contrato equilibrado no qual ambas as partes têm direitos de negociação razoáveis e devem ser respeitadas.

De acordo com isso, o melhor entendimento ainda parece ser que, apenas haverá suspensão do processo, ou até mesmo, a extinção da ação diante da alegação por uma das partes como matéria de defesa. 
Assim, poderá ocorrer a suspensão condicional do processo no artigo 313 do CPC, que pode ficar suspenso até seis meses, ou então, conforme previsão na Lei no 13.140 , que é a Lei de Mediação, a possiblidade de suspensão do processo para que a partes busquem conciliação ou mediação.

Isso significa que somente as exceções levantadas pelas partes podem paralisar verdadeiramente o processo judicial, para que as cláusulas de paz acordadas possam ser efetivamente observadas.

A segunda espécie elencada por Trigo (2020. p. 136) é o pactum de non exequendo, uma hipótese específica do pactum de non petendo.

Essa modalidade compreende-se como uma limitação da propositura da ação executiva. Isso porque, são normas de negócio executivo unilateral, pelo qual o credor compromete-se a não requer a execução de um título executivo.

Em suma, o credor promete não intentar com ação executiva, podendo-se valer de outros meios para cumprimento da obrigação.

Apesar de ser a princípio unilateral, nada impede que seja inserida em contrato bilateral, ou plurilateral e que seja consequentemente precificada, ou seja, que receba o credor por sua promessa uma contraprestação.

Tem se entendido atualmente, que o negócio jurídico processual defende que o pactum de non exequendo é um acordo material com efeitos reflexos sobre o direito processual. Em outras palavras, tal promessa incide sobre o vínculo obrigacional e não diretamente sobre o processo, mas pode acabar reverberando em eventual demanda executiva.

A terceira espécie de promessa de não processar, é a cláusula solve et repete. De maneira geral, para Trigo (2020, p. 150), é aquela cláusula "por meio do qual, determinada pessoa se obriga diante de cobrança de dívidas a não questionar qualquer aspecto de forma imediata, sem que antes pague aquilo que o credor demanda".

No Brasil essa espécie de pato é frequentemente lembrada no direito tributário, uma vez que, nessa área do direito é imposta por uma das partes da relação tributaria, parte essa que busca resguardar, ao máximo possível, seus créditos.

Percebe-se que nas relações tributários o Estado impõe prévio pagamento ao contribuinte, onde esse não tem qualquer margem de negociação do tributo, evidenciando abusiva a imposição de tal condicionante. Isso não ocorre nas relações entre civis e empresariais, pois aqui, as partes negociam ambos direitos e deveres.

É justamente por isso, que não se vê atualmente a cláusula solve et repete em outros ramos do direito além do tributário, pois ela está condicionada ao atendimento de um requisito bem especifico: o adimplemento.

Em outras palavras, o autor (2020, p. 152) explica que a cláusula solve et repete pode ser lida da seguinte forma: “determinada pessoa promete não propor determinada ação ou apresentar defesa enquanto não efetuar o pagamento de quantia cobrada pelo credor".

Por fim, existem diversas outras possíveis formas de aplicação das cláusulas de não postular, ampliando, restringindo, usando em casos gerais ou em demandas específicas, o que vem ganhando espaço no Brasil e tornando-se assunto relevante a ponto de ser estudado, compreendido e aplicado na prática jurídica do dia-a-dia.

\subsection{O pacto de non petendo aplicado à conciliação, mediação e arbitragem}

A Conciliação está regulamentada pela Lei no 13.140/2015 que é a Lei de Mediação, e tanto ela quanto o CPC tratam a conciliação como um sinônimo da mediação. Ocorre que, na prática existe uma diferença entre ambas.

Enquanto que na conciliação a técnica utilizada para aproximar as partes é mais direta, onde o conciliador busca a efetiva construção e sugestão na resolução do conflito, na mediação a técnica é voltada para aproximar as partes, ou seja, o mediador interfere menos nas soluções e foca mais na aproximação entre as partes.

O Conselho Nacional de Justiça - CNJ difere bem a conciliação da mediação, vejamos: 
A Conciliação é um método utilizado em conflitos mais simples, ou restritos, no qual o terceiro facilitador pode adotar uma posição mais ativa, porém neutra com relação ao conflito e imparcial. É um processo consensual breve, que busca uma efetiva harmonização social e a restauração, dentro dos limites possíveis, da relação social das partes.

A Mediação é uma forma de solução de conflitos na qual uma terceira pessoa, neutra e imparcial, facilita o diálogo entre as partes, para que elas construam, com autonomia e solidariedade, a melhor solução para o conflito. Em regra, é utilizada em conflitos multidimensionais ou complexos. A Mediação é um procedimento estruturado, não tem um prazo definido e pode terminar ou não em acordo, pois as partes têm autonomia para buscar soluções que compatibilizem seus interesses e necessidades.

As duas técnicas são norteadas por princípios como informalidade, simplicidade, economia processual, celeridade, oralidade e flexibilidade processual.

Os mediadores e conciliadores atuam de acordo com princípios fundamentais, estabelecidos na Resolução ${ }^{\circ}$ 125/2010: confidencialidade, decisão informada, competência, imparcialidade, independência e autonomia, respeito à ordem pública e às leis vigentes, empoderamento e validação.

Assim, o artigo 165 do Código de processo Civil difere esses métodos. O conciliador atua preferencialmente nas ações, onde não há vínculo entre as partes, e pode sugerir soluções, como ocorre nos Juizados Especiais Cíveis e nas Varas Cíveis. A mediação atua sobre ações nas quais as partes possuem vínculos, com o objetivo de restabelecer o diálogo e permitir que elas proponham soluções para o conflito, por isso, geralmente ocorre com mais frequência nas Varas de Família.

Por isso, tem-se que a mediação, como num todo, servindo até para conceituar conciliação, é uma técnica de negociação na qual um terceiro, indicado ou aceito pelas partes, as ajuda a encontrar uma solução que atenda a ambos os lados.

E para isso, o artigo $5^{\circ}$ dessa mesma Lei, prevê que a técnica deva ser pautada nos seguintes princípios: (i) imparcialidade; (ii) igualdade entre as partes; (iii) oralidade; (iv) informalidade; (v) vontade das partes; (vi) busca do senso comum; (vii) confidencialidade; e (viii) boa-fé.

Qual pessoa que tenha um processo na Justiça pode tentar resolvê-lo de forma negociada, usando a conciliação ou mediação. Vale para qualquer ação tramitando na Justiça Estadual, Justiça Federal ou na Justiça do Trabalho.

Todos os acordos obtidos por meio de conciliação ou mediação tem força de decisão judicial, pois serão de fato homologados por um juiz. Aqui, ninguém sai perdendo, as partes decidem o que é melhor para elas.

A Arbitragem, por sua vez, é regulada pela Lei $9.307 / 96$ e depende de convenção das partes, em cláusula específica e expressa em contrato, para ser aplicada.

Aqui a via judicial é afastada e permitem que terceiros, chamados de árbitros, onde geralmente possuem um vasto conhecimento sobre a matéria discutida, decidam a lide.

Esses árbitros atuam como juízes privados, e todas as suas decisões possuem eficácia de sentença e não podem ser objeto de recurso.

Ambos os instrumentos, contém um grau de consensualidade extremamente elevado, e é muito mais interessante resolver o conflito por essas vias do que levar para a judicial, por diversos motivos, como celeridade e economia processual, evitar a morosidade da ação, resolvendo o conflito de forma mais rápida, menos onerosa e menos desgastante.

A ideia de que as partes fazem parte da solução do litígio é fundamental para que o litígio seja de fato resolvido. Afinal, ninguém resolve o litígio, o judiciário apenas decide, sendo que o conflito continuará subjacente, não deixou de existir animosidade. Assim, incluir as partes no contexto decisório faz com que elas fiquem minimamente satisfeitas com a decisão, por mais que não sejam necessariamente vitoriosos.

Dessa forma, a ideia de que as partes estiveram presentes desde o início do conflito, tentando resolver juntamente e negociando cada aspecto dessa relação processual, é fundamental, uma vez que fica muito mais fácil em termos de aceitabilidade da decisão, afinal, a partes acompanhou, ajudou e decidiu desde o início.

Destarte, nesse contexto, tem-se que para os leigos os fóruns são lugares muito distantes, os juízes são seres muito distantes, que o ambiente é muito frio, complexo e inóspito, e assim, ajudando, contribuindo e decidindo a parte se sente mais 
acolhida e consequentemente fica mais tranquilo aceitar um desfecho para a solução do problema, mesmo que muitas vezes não seja satisfatório.

\section{Conclusão}

Buscou-se entender sobre negócio jurídico, onde o mesmo teve a primeira aparição no Código Civil Alemão (BGB), aparecendo somente no Código Civil de 2002. Assim, define-se negócio jurídico como um ato ou vários atos que se relacionam entre si, com finalidade negocial (declaração expressa), praticados espontaneamente (vontade) por uma ou mais pessoas com a intenção de satisfazer seus interesses, tendo como fim a produção de efeitos jurídicos com a finalidade a aquisição, modificação ou extinção do direito.

Nesse sentido, importante a análise dos dois principais princípios que regem o pactum de non petendo, quais sejam, (i) o respeito ao autorregramento da vontade das partes, onde está vinculado a ideia de liberdade, as partes são livres para decidirem sobre os dispositivos contratuais; (ii) e o princípio da cooperação, tendo como objetivo o combate ao desperdício, a tomada de decisões com base no mérito e não em decisões processuais, a busca da verdade e a utilização de métodos administrativos adequados à efetivação de direitos.

Por fim, por meio de um breve histórico do surgimento do pactum de non petendo, conceituou-se, esclarecendo alguns pontos e entendo sobre essa forma de pactuar e como aplicar na prática jurídica. Ainda, foi apresentado as três espécies de cláusulas, sendo elas: (i) cláusula de mediação; (ii) pactum de non exequendo; (iii) e, cláusula solve et repete. Dispondo ainda, sobre a necessidade e importância das conciliações, mediações e arbitragens em relação a promessa de não processar.

A importância do referido pacto e sua contemporaneidade, denotam-se em razão da nova interpretação advinda dos meios consensuais de conflitos, reforçada pelo vigente Código de Processo Civil. Se há meios passíveis de serem utilizados para que se cumpram os princípios do acesso à justiça e da razoável duração do processo, estes devem ter sua aplicabilidade reconhecida.

\section{Referências}

Alexy, R. (2008) Teoria dos direitos fundamentais: Malheiros.

Amaral, F. (2003) Direito Civil. Introdução. (5 . ed.) rev. aum. e atual. de acordo com o novo Código Civil. São Paulo: Renovar.

Barroso, L. R. (1999) Interpretação e aplicação da Constituição: fundamentos de uma dogmática constitucional transformadora: Saraiva.

Conselho Nacional de Justiça. Conciliação e Mediação.

Cunha, L. C. da. (2016) Art. 6. ${ }^{\circ}$ In: Streck, Lenio Luiz; Nunes, Dierle; Cunha, Leonardo Carneiro da (Org.). Comentários ao Código de Processo Civil: Editora Saraiva, 41-44.

Didier Jr., F., \& Cunha, L. C. da. (2015) Curso de Direito Processual Civil. (8ª . ed.) Vol. 3. Salvador: Juspodivm.

Dinamarco, C. R., \& Lopes, B. V. C. (2017) Teoria geral do novo processo civil. (2a . ed.): Malheiros.

Farias, Cristiano Chaves de; Rosenvald, Nelson. (2016) Curso de Direito Civil: parte geral e LINDB. V.1, 14 ed. Salvador: Juspodivm.

Fiuza, C. (2016). Direito Civil: curso completo. (18 a ed.): Revistas dos Tribunais.

Gagliano, P. S. (2012) Novo Curso de Direito Civil: Parte Geral: Saraiva Editora.

Gagliano, P. S., \& Pamplona Filho, R. (2020) Novo curso de direito civil. Imprenta, Saraiva.

Gonçalves, C. R. (2014) Direito civil brasileiro: responsabilidade civil. Vol 4.(9a ed.): Saraiva.

Hatoum, N. S., \& Bellinetti, L. F. (2016, outubro) Aspectos relevantes dos negócios jurídicos processuais previstos no art. 190 do CPC/2015. Revista de Processo, São Paulo, n. 260, 49-71.

Lakatos, E. M., \& Marconi, M.A. (2003). Fundamentos de Metodologia Científica: Atlas.

Leite, G. (2020) Teoria do Fato Jurídico. 
Research, Society and Development, v. 10, n. 6, e32510615714, 2021

(CC BY 4.0) | ISSN 2525-3409 | DOI: http://dx.doi.org/10.33448/rsd-v10i6.15714

Lotufo, R. (2004) Código Civil Comentado. Vol. 1 e 2. (2ª ed.) atual: Saraiva.

Medina, J. M. G. (2013, agosto) Afinal de contas, o que é um princípio jurídico? Revista Consultor Jurídico, São Paulo.

Medina, J. M. G. (2017) Novo Código de Processo Civil comentado: com remissões e notas comparativas ao CPC/1973. (5a. ed.): Revista dos Tribunais.

Miranda, P. de. (1954) Tratado de Direito Privado: Parte Geral: Borsoi. t. 3.

Miranda, P. de. (1999) Tratado de Direito Privado: Parte Geral: Bookseller Editora.

Mello, M. B. de. (1991) Teoria do fato jurídico. (4⿳a. ed.): Saraiva.

Moreira, J. C. B. (1984, janeiro-março) Convenção das partes sobre matéria processual. Revista de Processo, São Paulo, vol. 33, $182-191$.

Nery Junior, N. (2010) Princípios do processo na Constituição Federal: processo civil, penal e administrativo. 10. ed. rev., ampl. e atual. com as novas súmulas do STF (simples e vinculantes) e com análise sobre a relativização da coisa julgada. São Paulo: Revista dos Tribunais.

Neves, D. A. A. (2016) Novo Código de Processo Civil Comentado: Juspodivm.

Nogueira, P. H. (2016) Negócios jurídicos processuais. (2ª ed.): Juspodivm.

Pereira, C. M. da S. (2009) Instituições de Direito Civil. Vol. IV. Direitos Reais. 20 ed. De acordo com o Código Civil de 2002. rev. e atual. Por Carlos Edison do Rêgo Monteiro Filho. Rio de Janeiro: Forense.

Pereira, C. M. da S. P. (1997) Instituições de Direito Civil. (15ª ed.): Forense.

Ramos, C. A. (2007, outubro) A concepção republicana de liberdade como não-dominação. Crítica: Revista de Filosofia, Londrina, 12(36), $301-336$.

Reale, M. (2004) Lições Preliminares de Direito. (27ª Ed.): Saraiva.

Trigo, A. L.A. da C. (2020) Promessa de não processar e de não postular: o pactum de non petendo reinterpretado: Editora JusPodivm. 